\title{
APPLICATION OF INFORMATION COMMUNICATION TECHNOLOGY IN THE WORK OF JUDICIAL AUTHORITIES
}

\author{
Aleksandra Jovanović34 \\ Nikola Jovanovic ${ }^{35}$
}

https://doi.org/10.31410/itema.2018.91

\begin{abstract}
In order to improve the efficiency, accountability and transparency of the work of judicial authorities and the establishment of a modern and user-friendly system of judiciary, it is necessary to build contemporary information systems with the needs of the judiciary. The unique information system applied in the judicial system enables: optimizing human resources; rationalization of financial resources; automating and reducing, as far as possible, the impact of the human factor on the efficiency of the work of judicial authorities; reducing paper documentation and introducing e-data and their electronic exchange between judicial authorities and other state institutions.

An ever growing trend in the development of the information and communication technology system leads to its penetration into numerous systems and pores, and thus in the legal system, and imposes the needs of an adequate strategy and reform of the judicial system followed by the introduction of the electronic-cyber court.
\end{abstract}

Keywords: information communication technologies, justice system, e-justice system, strategy, cyber court

\section{Introduction}

The judicial system is continuously being harmonized with the needs of society and organization of work in accordance with contemporary trends and globalization. The development of information and communication technologies is unbearable in the legal system and imposes the need for changes in its functioning. Nevertheless, the system of judiciary largely lags behind in the application of modern information and communication technologies in relation to other activities. The application of modern ICTs would be accompanied by an increase in efficiency by reducing costs and satisfying the users of court services. The application of video technologies in the judiciary system would contribute to more efficient work. Accessibility to the global network would allow video meetings of spatially distant parties (the accused, the judge, the lawyer, etc.) and make the court processes much cheaper than the classic way of their work. The electronic - cyber court is the basis of the model of the work of the future judicial system. Due to the many benefits of new technologies, more and more application of scientific achievements in the work of the judiciary is expected, accelerated development and wider representation of information and communication technologies.

Information and Communication Technologies (hereinafter: ICT) revolutionized the way of life, learning, work and entertainment in just one human generation. ICTs increasingly transform the way people, businesses and public institutions interact.

\footnotetext{
${ }^{34}$ Faculty of Law, Security and Management Konstantin Veliki, Niš, Zetska 2, Serbia

${ }^{35}$ Faculty of Mechanical Engineering, Nis, Serbia
} 
Total changes in all aspects of the society that are enabled by the use of ICT make the development of the information society.

The aim of the paper is to point to the importance of increasing efficiency and economy in the work of judicial authorities that enable contemporary ICTs to its benefits.

\section{Electronic cyber court and cyber courtroom}

Electronic - cyber court includes virtual courtrooms, online dispute resolution, electronic document submission and video conferencing. It enables the involvement of mediators and judges who have the skills, experience and knowledge in making urgent and complex decisions. The cyber court contributes to the faster, easier and cheaper solution of court proceedings.

The electronic courtroom, equipped with adequate video conferencing equipment, allows the judge, witness and accused person who is spatially dislocated to communicate and "live in a virtual space". By 2020, citizens will be able to do all the contacts with the administrative bodies, the holders of public powers, the courts and the health care system, except those contacts which in their nature require a physical presence, without leaving their apartment or workplace.

A virtual courtroom allows the indicted to be indirectly present at the video trial. In the courtroom, the Prosecutor's Office and, possibly, the accused' attorney are directly present, with the attorney being able to attend the trial and from the police station or detention where his client is located. This possibility is hampered by laws and regulations in Serbia, as well as in many other countries that allow video evidence testimony only in case of justified prevention of presence in the courtroom itself, as well as for security reasons. It is necessary to change them in order to save time and financial resources. The amendment would also refer to the recording of the trial process on the compact disc, which would exclude the recruiters' engagement. The process would start by filing a lawsuit and paying the fee electronically, then by determining the location of the cyber trial (location determined by the court). The cyber court, in accordance with the law in individual cases, can be open type so that interested parties can follow the court process through a video link.

The use of ICT reduces with the duration of court proceedings. It is also necessary to establish a system that is easy to handle in order to overcome the classic way of collecting, classifying, storing and downloading documents of a court process, for which only one person is in charge. Such a system would enable judges and interested parties to have regular access to court documents, and the real-time transcript would allow monitoring of the entire course in the trial, as opposed to the classic way of monitoring the trial in which the record is kept and every spoken word is recorded. At the end of the day the transcript would be indexed and added to the court database, which would make it easy to search.

The introduction of a virtual courtroom in court does not require big money investments in hardware and software from the parties. Each virtual courtroom should have a local network connected to the Internet and equipped with a computer system for support, presentation and transcript of documents, a sophisticated audio-visual system and video conferencing.

The creators of the first Australian virtual courtroom, Auscript and Counsel's Chambers Limited, are hoping that the classic courtroom will be replaced by modern cyber courtrooms. 


\section{Legal changes}

In order to apply ICT in the judicial system, legislative changes are needed to allow information in electronic form to be treated as evidence and documents can be electronically signed. Online security can affect the integrity of judicial documents. On the other hand, this would allow public access to court documents in contrast to court documents obtained in paper form or raised at court counters, which can also be obtained electronically on a device similar to a banking ATM device operating in the new conditions. Queries can be posed from a number of legal areas such as: alternative dispute resolution, execution of judgments, housing and occupancy rights, divorce and other minor issues. The dialog starts with the list of legal areas on the device monitor. After selecting the desired area, the device sets up queries to which the user responds by simply typing the keyboard response. When a user collects all the necessary information, the document can be printed out, and the instructions received along with the documents indicate the activities that should continue to be performed. Some documents have to be certified by the court, some have to be submitted to court, some should only be excavated, while some documents can only serve as a guide.

\section{Privacy}

Public authorities must take into account the interest of the private person and the public interest, which will lead to the censoring of certain private or personal data. This would solve the problem of conflict between the public and the individual between the right of the public to obtain court information and the rights of every individual to maintain and protect their privacy. The process of designing and implementing an efficient electronic justice system involves the participation of all actors in the process (defendants, police officers, trial reporters, lawyers, staff responsible for maintenance of technical equipment, witnesses, etc.) from the very beginning of the process. In order to design a quality system, it is necessary to fully understand the problems of all participants in the trial, to solve it, and thus to improve the trial process.

In order to design an adequate system and the quality application of video conferencing in the courtroom, it is necessary to: apply research methods such as interviews and discussions in order to reveal attitudes; to form a personal profile of persons of different groups in order to meet the needs of stakeholders; conduct a flow analysis, which creates a visual representation of information or activities that include a day in the court, involving the defendant, lawyers, case history, records, and more. The flow analysis can then be used to identify so-called "bottlenecks" and find alternatives to achieve the same goals, but in a different way. Particular attention can be focused on activities that take place wrongly. It is then necessary to analyze the functioning of courtrooms throughout history, but also in the future, by focusing attention on social, cultural and technological trends over time, which will affect the future in their development. These advantages point to the necessity of implementing new technologies in the existing court practice and creation of a court of the twenty-first century with new visions. In order to achieve these goals, special attention should be paid to the modernization of the judiciary, the selection of high-quality video conferencing equipment and the engagement of experts in the field whose task would be to determine important viewing angles, screen positions, cameras, microphones, speakers.

\section{Electronic complaints and archiving}

The basics of cyber courtroom can be seen through analysis of electronic complaints and archiving. ICT development and computerization involves the transfer of classic documents 
into electronic form. The advantage of electronic submission of documents to courts and stakeholders saves time; reduces the cost of using paper; reduces travel expenses; eliminates duplication of data and ensures the reliability of their storage; enables the continuous submission of documents, not only during the working hours and on the working days of certain authorities. The advantage is a digital signature that guarantees the integrity of the document. Potential theft of electronic documents is beyond the provision of copies in the court database that is updated at regular intervals. Disadvantages of working with electronic documents are: interrupting data flows and entering the electronic court system; the inability of all persons to submit a document in electronic form (solution: submitting a document on paper that can be scanned and transferred in an appropriate electronic form).

In spite of all the benefits of the modernized judiciary, the defendants' lawyers generally consider that they can best communicate with prosecutors, witnesses, judges and the client live - in the courtroom. The problem with virtual courtrooms is the difficulty in cross-examination through video technology. Court interpreters do not match modern technology due to lack of contact with defendants. Unfairly for prisoners is "abolishing" their "day in court". It should be emphasized that one of the main obstacles to faster and more successful adaptation to technological innovations in many countries is the legislative system of civil law, where the most important preconditions for the validity of paper and the physical signature of the documents are. Cultural change and change in people's awareness are essential factors that are necessary for the successful introduction of ICT into the judicial system.

\section{Application of ICT in the judiciary of Serbia}

The development of the information society should be directed towards the utilization of ICT potentials for increasing labor efficiency, economic growth, higher employment and improving the quality of life of all citizens of the Republic of Serbia. The development engine of the information society consists of: - open, all accessible and high-quality Internet access; developed e-commerce, including: e-government, e-commerce, e-justice, e-health and eeducation.

The insufficiently regulated state of justice in Serbia is an ideal ground for the implementation of ICT, especially video technology. Even simple judicial processes are inadmissibly long lasting, often the processes are prolonged for two to three decades, and some never end. It is present with the lack of verified interpreters of certain languages, which leads to the statute of limitation after ten years of prolonging the courts. Failures of such a judiciary, as well as the entire state order, incompetence, lack of interest and lack of information of judges, even corruption, but also exerting pressure on judges from various parties imposes the need for a radical reform of the judiciary. Serbia looks at computerization among the last countries in the region, but cyber courtrooms or virtual courts in Serbia are still far from reality. Bearing in mind the poor situation in the Serbian judiciary, it is unrealistic to expect its modernization in the near future. In 2006, the Government adopted the Information Society Development Strategy in the Republic of Serbia ("Official Gazette of the Republic of Serbia" No. 87/06), which completely regulates the area of information society.

Two specially equipped courtrooms were opened in the District Court in Belgrade for the needs of the Department of High-Tech Crime, renovated with funds provided by the Ministry of Justice of Serbia. Renovation and equipping of courtrooms cost about 16 million dinars. Courts 3 and 4 are equipped with modern electronic equipment and a video link with the District Court building and there is a room for directing. The courtrooms also have cabins for protected 
witnesses with the technical possibility of distortion of image and sound, as well as cabins for translators and journalists.

e-Pravda provides a complete integrated system that supports the basic processes and operational activities of the judiciary and provides the basis for measuring the results of work according to standards to be established with indicators that the judiciary will only define to measure the achieved degree of reform goals (independence, transparency, accountability and efficiency). ICT infrastructure will enable the connection of all judicial authorities and other state bodies, which will enable the daily updating of data on judicial cases and efficient exchange of information and electronic documents of participants in the e-Pravda system and the environment, in accordance with the law.

\section{Unique judiciary ICT system}

The judicial information system was conceptually conceived as a unique information system that would cover the needs and key business processes of the Ministry of Justice, courts, the State Prosecution Office and the Penal Enforcement Bureau. The ISP implies the integration of the information systems of each individual organizational unit in a way to comply with all legal procedures and regulations defining the activities, competencies and responsibilities of these organizational units. Such a unique system should ensure the centralization and efficient organization of data without redundant and repeated data, to define data entry standards, generate reports and records, and transparent structure of process and data flows within, and between, institutions that would allow for further upgrading and improvement of the judicial system. The functionality of the information system should provide automation of business within the organizational units of the judicial system in such a way that all processes are implemented using appropriate subsystems of the information system, including data entry, input of complete documents, recording of all changes during the implementation of procedures in the daily activity of organizational units, simple search documentation in electronic form, efficient generation of reports from the system according to various set parameters. Such a system should also ensure the integrity of data, documents, objects, and files that are updated and used within the system. Shared data usage and unique input increase work efficiency, reduce the time frame of the procedures envisaged, the costs of printing and sending documentation, and the ability to produce various analytical and statistical reports based on data entered in the information system. Finally, the true dimension of a single information system can be seen in the ability to control the efficiency and quality of operation of all units within a single information system through automatic generation of reports, making comparative analyzes. Applying these measures indirectly affects the increase of the responsibility of the holders of judicial functions and other employees in the judicial sector. The goal of introducing a single information system is to optimize time resources, streamline financial and human resources, automate procedures and neutralize as much as possible the impact of human factors on efficiency, then to avoid as much as possible paperwork, enable electronic data exchange and documents between judicial institutions and other state and international institutions. The development and implementation of a single information system must also enable greater transparency of the work of judicial institutions and easier access to justice, through the availability of electronic and multimedia channels of communication with citizens and the general public. 


\section{Conclusion}

The inevitable conclusion is that the legal world is far behind the business world regarding the application of modern technologies. One of the reasons is that the business world fully recognizes and uses the advantages of electronic storage and information sharing. Cultural change and change in people's awareness are essential factors that are necessary for the successful introduction of ICT into the judicial system. There is still a certain amount of resistance to the introduction of modern technologies into court processes, often behind the rejection of everything that is naturally hindered by unwillingness to personalize and master advanced technologies.

Before the judiciary, it is imperative to accept new technologies in order to solve a number of accumulated problems that should be singled out: a constant increase in the number of cases, the complexity of the case, jurisdiction, limited resources, pressure for improved access to justice and the necessity of raising the level of efficiency of the judicial administration. In the time of the judges' for a certain period, in addition to high expertise, judges will have to master the skills in the application of modern technologies in the administration of justice. The Internet provides the judiciary with a wide range of options and its application can help both the preparation of the trial.

In practical application, cyber courtroom benefits are manifested through the reduction of delays in the process, raising the level of security (it is easier to keep inmates in prisons than in transport), better experience for prisoners (especially those who do not like transport), improving cross-border legal cooperation and other. It is to be expected that the pace of innovation of the judiciary will accelerate and that cyber courtrooms will give full contribution to more efficient and more economical work. The development of electronic courtrooms in the world should be a guide to the Serbian judiciary primarily in overcoming inertia, which is recognizable beyond the borders of the country, as well as in raising the quality of services. The process of modernizing the judiciary is inextricably linked to social and cultural heritage. As changes are needed in these areas, patience and perseverance in the innovation of the judiciary is implied. The Internet with a number of its services makes it possible to relieve courts and increase their efficiency. The Internet can be used at all stages of the court proceedings, from electronic submission of documents, through the trial itself and virtual courtrooms, to the final court decision. Finally, modern technologies have opened many doors; it's just a matter of how and in what way all these opportunities will be used in the judiciary. The application of modern information technologies, standardized software and a unified system for the management of cases in the judiciary are necessary in order to efficiently implement the key principles of effective justice: independence, transparency, accountability and efficiency.

\section{REFERENCES}

Alempije Veljović A. Vulović R., Damnjanović A., Informaciono komunikacione tehnologije u menadžmentu . Čačak : Tehnički fakultet, 2009 (Čačak : Svetlost)

Dragović,LJ., Nikolić, M., Nikolić, M., Nikolić, Z.: Telemedicine - Electronic Health Care, 5th International Conference Economics and Management - Based on New Technologies, EMoNT 2015, Proceedings, Serial number of paper A-15, pp. 243-248, 18-21. June 2015, Vrnjačka Banja, Serbia.

Dušan M. Informaciono-komunikacione tehnologije / Kostić Beograd : Beogradska poslovna škola - Visoka škola strukovnih studija, 2011 (Beograd : Nauka i društvo) 
Nikolić, Z., Sokolović,V., Nikolić, M.: Electronics Banking - The Future of Banking Business, 2nd International Conference Economics and Management - Based on New Technologies, EMoNT 2012, Proceedings, Plenary and Invitation Paper, Serial number of paper P-7, pp. 65-76, June 2012, Vrnjačka Banja, Serbia.

Nikolić, Z.: Elektronska razmena podataka, udžbenik, Fakultet za industrijski menadžment u Kruševcu, ICIM plus - Izdavački centar za industrijski menadžment plus, Kruševac, 2007.

Pollicino O, Romeo G., The internet and constitutional law: the protection of fundamental rights and constitutional adjudication in Europe , London ; New York : Routledge, Taylor \& Francis Group, 2016

Rafovanović Š.,Informaciono - komunikacione tehnologije : uspon digitalne ekonomije,Visoka poslovna škola strukovnih studija, 2009 (Niš : Sven)

Stedžers P., Korupcija, transparentnost i prostor za informaciono-komunikacione tehnologije / Pol Sterdžes ; prevela s engleskog Gordana Ljubanović str. 9-20

Strategija razvoja informacionog društva u Republici Srbiji ("Službeni glasnik RS", broj 87/06 Strategiju razvoja informacionog društva u Republici Srbiji do 2020.("Službeni glasnik RS", broj 58/2010)

Zakon o elektronskoj trgovini ("Službeni glasnik RS", broj 41/09)

Zakon o elektronskom dokumentu ("Službeni glasnik RS", broj 51/09) koji uređuje upotrebu elektronskog dokumenta, kao i vremenski žig.

Zakon o elektronskom potpisu ("Službeni glasnik RS", broj 135/04) koji implementira EU propise koji uređuju elektronski potpis.

Zakon o potvrđivanju Konvencije o visokotehnološkom kriminalu i Zakon o potvrđivanju Dodatnog protokola uz Konvenciju o visokotehnološkom kriminalu koji se odnosi na inkriminaciju dela rasističke i ksenofobične prirode izvršenih preko računarskih sistema ("Službeni glasnik RS", broj 19/09)

Zakon o telekomunikacijama ("Službeni glasnik RS", br. 44/03, 36/06 i 50/09 - US)

Zakon o zaštiti podataka o ličnosti ("Službeni glasnik RS", br. 97/08 i 104/09) 